\title{
ラット下顎頭関節軟骨線維層の微細構造と細胞分裂能に関する実験的研究
}

\author{
水野有功・佐分利紀彰・田口望 \\ 金田敏郎・星野 洸*
}

\section{The experimental study of the fine structure and cell-mitotic activity of the fibrous zone of articular cartilage in the rat mandibular condyle}

\author{
Isao Mizuno • Noriaki SAburi • Nozomu TAgUchI \\ Toshio Kaneda - Takeshi Hoshino*
}

\begin{abstract}
Three week-old and 6 week-old rats were given intraperitoneal injections of colchicine in a 0.05 percent saline solution, the dosage was $1 \mathrm{mg} / \mathrm{kg}$ body-weight. Accumulation of arrested metaphases in the fibrous zone of the mandibular condyle could be observed. Light microscope study of the plastic-embedded semithin sections of mandibular condyle identified two layers $\left(F_{1}\right.$ layer and $F_{2}$ layer) in the fibrous zone. In these two layers age related changes of the tissue structure were obserbed.

It is shown that the fibroblast-like cells in $F_{1}$ and $F_{2}$ layers have mitotic division ability as old as 6 weeks of age, and that the $F_{1}$ layer tended to disapper before 6 weeks, while the $F_{2}$ layer became thicker because of a conspicuous formation of thick bundles of collagen fibers in the matrix.
\end{abstract}

Key words: fibrous zone of mandibular condyle, mitotic activity, colchicine

緒

言

下顎頭関節軟骨表層は，長管骨の関節とは異なり，強 勒な膠原線維束と線維芽細胞様細胞からなる線維性結合 組織, すなわち, 線維層によって覆われている。この線 維層は顎運動の活発化につれて, その厚みを増すといわ れている ${ }^{1,2}$. さらに, 線維層基質の強勒な膠原線維束 が内部の軟骨を被覆し, 下顎に加わる力の緩衝部位とし て，関節円板とともに重要な役目があるとされてい

名古屋大学医学部口腔外科学講座

（主任：金田敏郎教授）

* 名古屋大学医学部解剖学講座

（主任：星野 洸教授）

Department of Oral Surgery, School of Medicine, Nagoya University (Chief: Prof. Toshio Kaneda)

* Department of Anatomy, School of Medicine, Nagoya University (Chief: Prof. Takeshi Hoshino)

受付日：昭和 63 年 5 月 25 日
る $^{3)}$.

ラット下顎頭の構造については,すでに解剖学的, 組 織学的な検索が数多く行われている ${ }^{2 \sim 7)}$. しかし, 線維 層の微細構造に関する詳細な報告は少なく ${ }^{8 \sim 10), ~}$ 線維層 の線維芽細胞様細胞の動態 ${ }^{11)}$ に関して, 不明な点も多 い. 今回，われわれは，3週齢と6 週蹂のラットに, コ ルヒチン投与を行らことによって，これまで，分裂能は ないとみなされていた2）線維層の線維芽細胞様細胞に, 分裂像を見い出した。ささらに，線維層を形態学的に二層 $\left(\mathrm{F}_{1}\right.$ 層, $\mathrm{F}_{2}$ 層) に区分し, 加龄による線維 層 $\left(\mathrm{F}_{1}\right.$ 層, $\mathrm{F}_{2}$ 層) の分裂能の推移ならびに組織変化について検討 を行った。

\section{実 験 方 法}

生後 3 週龄と 6 週龄のウイスター系雄性ラットおのお の10匹を使用し, 実験群と対照群に分けた。実験群に は, $0.05 \%$ コルヒチン溶液を $1 \mathrm{mg} / \mathrm{kg}$ の割合で10時, 13時，16時の時刻に計 3 回腹腔内投与した。18時に実験 群扣よび対照群ラットをエーテル麻酔後, 耳前切開, 皮 
下組織，関節の剝離，下買頭露出，下䫇頭頸部切開によ り下顎頭を採取し，観察材料とした。採取後，ただちに $2.5 \%$ グルタールアルデヒドと $2 \%$ パラホルムアルデヒ ド混合固定液（リン酸緩衝液 $\mathrm{pH}$ 7.4）中で, 下䫈枝長 軸に平行に, 厚さ約 $1 \mathrm{~mm}$ の前頭断切片を作製し, 浸漬 固定した。その後 $0.5 \mathrm{M}$ の EDTA-4 Na 溶液 (pH 7.4）にて脱灰し，通法飞従い土タノール系列にて脱水 後, ケトール 812 に包埋した。 そして, 超ミクロトーム （ポーター、ブラム MT 1 型）にて, ガラスナイフを 用い, 約 $2 \mu \mathrm{m}$ の連続切片を作製し，1\%トルイジンブ ルーで加温染色後, 光学影微鏡で観察した。

細胞分裂像関しては，作製した各下顎頭の連続切片 から, 約 $50 \mu \mathrm{m}$ 間隔每に切片 5 枚を取り出し, 線維層 および增殖細胞層の分裂像の観察を行った。細胞分裂像 は分裂中期にあるものを対象とし， 1,000 倍の光学顕微 鏡下で直接算定した。分裂像算定部位の線維層および增 殖細胞層の総細胞数は, 100 倍の光学顕微鏡下で写真撮 影し，360倍の写真上で算出した。

\section{実 験 結 果}

\section{1. 線維層の層区分について}

3 週齢ラットの約 $2 \mu \mathrm{m}$ の semithin 切片を詳細に観 察したところ，線維層を 2 層に区分できる所見を得た． すなわち，第 1 層（ $F_{1}$ 層） は関節腔に面する最表層で， $2 \sim 3$ 層の類円〜楕円形の細胞が, 関節腔に平行に, 比 較的密に配列し，下顎頭頸部付近では次第に滑膜細胞層 へと移行していく層である (写真 1，2）， $F_{1}$ 層の細胞 は，核の占める割合は大きく，紐胞突起をあまりもたな い(写真 3$)$ ）第 2 層 $\left(\mathrm{F}_{2}\right.$ 層) は, $\mathrm{F}_{1}$ 層之增殖細胞層と の間にあり, 扁平で, 樹枝状の形態をもつ細胞 4〜5 層
からなる細胞層である。この層は， $\mathrm{F}_{1}$ 層に比べ，細胞 密度が低く，下顎頭頸部付近では，次第に，下澦枝骨膜 外層へと連続していく凮である（写真 1， 2 ）。 $\mathrm{F}_{2}$ 層の 細胞は, 核の占める割合が小さく, 紐胞突起を, 主に, 関節腔に平行に長く延ばしている，また，基質はこの層 を特徽づける所見で， $F_{1}$ 層に比べ，太く強勒な膠原線 維束が関節腔に平行に配列し，細胞はこれらの膠原線維 束間に散在している (写真了)。これらの所見により， 線維層を形態学的に $\mathrm{F}_{1}$ 層および $\mathrm{F}_{2}$ 層の二層に明確に 区別できる（表 1 ）。

\section{2. 加柃による線維層の組織変化について}

6 週粭になると， $F_{1}$ 層の厚みは減少し，最裴層に 紏 胞は存在しなくなり， $F_{1}$ 層を層区分するのが困難にな っていた。こころが， $F_{2}$ 層は，膠原線維束が著明に增 加しているため, 著しく厚くなっていた。 したがって， $\mathrm{F}_{1}$ 層が衰退しているにもかかわらず，線維層全体とし ての厚さは 3 週齡より增加していた。 また， $\mathrm{F}_{2}$ 層の緗 胞形態は，比較的類円形をとるようになり，その細胞密 度は 3 週秢に比へ，減少していた（写真 4 a , b ).

\section{3. 線維層および增殖細胞層の細胞分裂について}

3 週齢の対照群では, 線維層 ( $\mathrm{F}_{1}$ 層, $\mathrm{F}_{2}$ 層) の線維 芽細胞様細胞に，細胞分裂像を観察した。細胞分裂像 は，下顩頭前頭断切片における頭頂部から滑膜移行部に いたる籁囲内で観察され，特定の部位に局在していなか った（写真 $5 \mathbf{a} ， \mathbf{b}$ )。 6 週踰の対照群では線維層の $\mathrm{F}_{1}, \mathrm{~F}_{2}$ 両層ともに細胞分致像は観察されなかった。し かし，実験群では， 3 週齡のみならず 6 週柃にも細胞分 列像を観察した。

各週路の対照群および実験群の細胞分到数を算定した 結果， 3 週粭では，実験群の $\mathrm{F}_{1}$ 層, $\mathrm{F}_{2}$ 層および增殖 細胞層は, 対照群に比し, 分裂の割合は有意に增加して

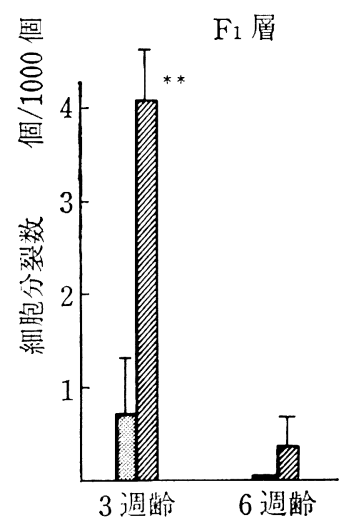

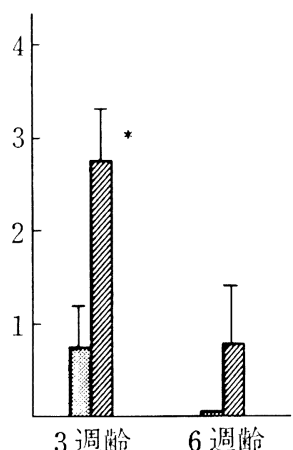

$* \mathrm{p}<0.01 * * \mathrm{p}<0.005$
増殖細胞層

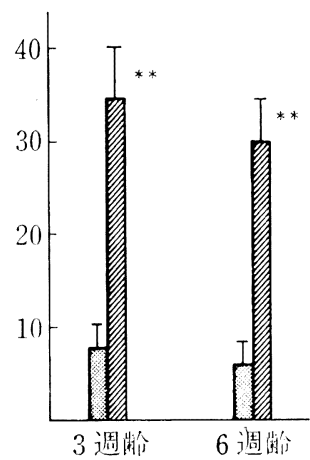

図 1 コルヒチン投与による紐胞分裂数の変化 
表 1 線稚㰾層区分

\begin{tabular}{|c|c|c|c|c|c|c|c|}
\hline & & 細胞密度 & 細胞形態 & 細胞突起 & 核 /細胞筫 & 基 質 & 層移行部 \\
\hline 楾 & $F_{1}$ 層 & 比校的密 & $\begin{array}{l}\text { 椌円形 } \\
\text { 類円形 }\end{array}$ & 短い & 大きい & $\begin{array}{l}\text { 柾で細い膠原 } \\
\text { 線維束 }\end{array}$ & 滑膜 \\
\hline 層 & $\mathrm{F}_{2}$ 譤 & 疎 & $\begin{array}{l}\text { 俩平で } \\
\text { 樹枝状 }\end{array}$ & $\begin{array}{l}\text { 著しく } \\
\text { 長い }\end{array}$ & $\begin{array}{l}\text { 比較的 } \\
\text { 小さい }\end{array}$ & $\begin{array}{l}\text { 密で太い膠原 } \\
\text { 線維束 }\end{array}$ & $\begin{array}{l}\text { 下顎枝 } \\
\text { 骨膜 }\end{array}$ \\
\hline
\end{tabular}

表 2 各層の細胞分裂蜜

個 $/ 1000$ 個 - 1 時間

\begin{tabular}{c|c|c|c}
\hline & 3 週秢 & 6 週柃 & 有意差 \\
\hline $\mathrm{F}_{1}$ 層 & $0.43 \pm 0.15$ & $0.07 \pm 0.05$ & $\mathrm{p}<0.01$ \\
\hline $\mathrm{F}_{2}$ 層 & $0.27 \pm 0.04$ & $0.10 \pm 0.09$ & $\mathrm{p}<0.01$ \\
\hline 增殖細胞層 & $3.26 \pm 1.00$ & $2.59 \pm 1.82$ & N.S. \\
\hline
\end{tabular}

$($ Mean \pm S.D. $)$

いた。しかし， 6 週秢になると，実験群の增殖細胞層に は, 3 週秢と同程度の分裂像の增加が認められ, 対照群 に比し有意差が認められたが, $F_{1}$ 層および $F_{2}$ 層の奉 験群と, 対照群間には有意差は認められなかった（図 1).

また，対照群と実験群の細胞分裂数の差をコルヒチン の作用時間で除することにより， $F_{1}$ 層， $F_{2}$ 層および增 殖細胞層の細胞分裂蜜（1時間当たり細胞 1000 個 当た り）を算出した（表 2 ）。この結果， $F_{1}$ 㬝および $F_{2}$ 風 は 6 週㱓になると分裂能は 3 週制より減少しているが， 增殖細胞層の分裂能は 3 週粭と 6 週路間に有意差は認め られなかった。

\section{考察}

\section{1. コルヒチン投与量および投与時間について}

今まで，多くの研究者により，上皮，腫揚細胞等の細 胞分裂率に関する车験に，コルヒチンが使用されてき $た^{12,13)}$ 。組織や動物によりコルヒチンの感受性が異なる ためコルヒチン投与量は，研究者によりさまざまであっ た。 コルヒチン投与量に関し, Viljamaa ${ }^{14 ~ 16)}$ ら (1976, 1981）は，ラット頭蓋顔面軟骨の分致能の奏験を，コル ヒチンの腹腔内投与により行った結果， $1 \mathrm{mg} / \mathrm{kg}$ では， 5〜10日龄の幼弱ラットには毒性が強すぎ，数時間しか 生きられず，細胞変性が著しいとし，20日粭のラットの

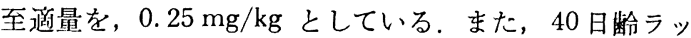
トでは， $4 \mathrm{mg} / \mathrm{kg}$ のュルヒチンを投与したところ，分 裂像が一番多く微察できたとしている。細胞分裂の日内 変動について，組織により若干の差買があるものの，11
一14時位に分裂能の高い時刻があると報告されてい る ${ }^{12,14)}$ 。また，コルヒチンは，腹腔内投与により，投与 後約45分で細胞分裂を阻止し始める。 その有効血中濃度 は投与後 $2 \sim 3$ 時間維持され，その時間内では，分裂像 が直線的に增加すると報告されている ${ }^{13,15)}$ また，頭蓋顔 面軟骨細胞では，コルヒチン投与後約 6 時間後に分裂像 の最高值が得られたとされている ${ }^{15)}$. 本実験では，線維 層の線維芽細胞様細胞之增殖細胞層の軟骨芽細胞の分裂 像を, 最も効率よくとらえるために，細胞分裂の日内变 動を考虑し，10時に $1 \mathrm{mg} / \mathrm{kg}$ のコルヒチンの腹腔内投 与を開始した。 その後, 血中濃度を維持するために, 3 時間ごとに計 3 回投与し, 初回投与から 8 時間経過後に 下顠頭を摘出した，実験群の分裂像には，コルヒチン投 与不足にみられる分裂後期, 終期にある分裂像はなく， 過量投与にみられる細胞变性像も認められなかった。よ って, 本実験のコルヒチン投与量および投与法は，分裂 期にある細胞の紡錗系の重合を阻害し, 線維層, 增殖細 胞層の分裂を止めるのに適当であったと思われる。

\section{2. 線維層の層区分および線維層細胞の動態について}

下罘頭関節㳄骨層の表層から一次骨梁にいたるまでの 細胞の形態的変化は，今まで Bloom ${ }^{4)}$ (1975), Durkin ${ }^{5}$ (1973)，Beresford6) (1975)，田ロ ${ }^{3)}$ (1980) らなど多く の研究者により下龥頭を各層に区分した報告がれれてい る、区分各層の名称は研究者によって異なるが，本質 的には同一の層区分と考兄られる場合が多かった。しか し，いずれの層区分も，線維層を一層としていて，本研 究のように線維層を二層に区分した報告はほとんとみら れなかった. Silva ${ }^{8)}$ (1967) らは, guinea pigの下䫇頭 を $\mathrm{I} \sim \mathbb{V}$ の 4 層に区分し，線維層に相当する層を zone I と Zone II の 2 層に区分している。 また，形態学的に Zone I , II の細胞は，增殖細胞層に相当する Zone II の 一部の細胞から由来していると示㖫している，ところが，

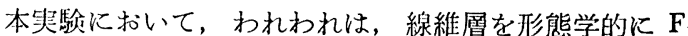
層と $\mathrm{F}_{2}$ 層に区分したが， $F_{1}$ 層と $F_{2}$ 層の線維芽細胞 様細胞は 6 週粭頃までは分裂能を示すことがわかった。 $\mathrm{F}_{1}$ 層では， 3 週桧以後 6 週秢までに分裂率は急速に低 下し，層は退縮する。，一方， $\mathrm{F}_{2}$ 層では増殖細胞層と比 べて低いながらも分裂能を示し，さらに 6 週路までに線 維性基質を大量に增加させている，つまり，成長期の線 維層の発育は, 内部の紐胞增殖と線維性基質の生産によ 
ってすすめられるとみなされる，線維層の下方にある增 殖細胞層では， 6 週跲になっても 3 週齢とほぼ同じ程度 に活発に分裂している，この層は，主に下顎頭軟骨へ細 胞を供給しており，上方の線維層へも細胞を供給するか 否かはなお不明である。

\section{3. 線維層の加齢による組織变化について}

Appleton ${ }^{9)}$ (1975) はラット下顎頭表層の 超微細構造 を観察し，20日龄では，関節腔表層からおよそ $25 \mu \mathrm{m}$ までは, 膠原線維束は比較的少なく, 線維芽細胞様細胞 が多数存在し, 関節腔に面する細胞は, 細胞突起を関節 腔に延ぱし, 滑夜の分泌もしくは栄養を滑液より取り込 んでいると推察している，また，80日龄では，関節腔表 層では細胞密度は減少し, 線維芽細胞様細胞が存在しな く, 基質が直接関節腔に面している部分があり，その基 質には，太い膠原線維束と比較的未熟な弾性線維が存在 するのを観察している．これらの組織変化は咬合および 顎機能と関節内の潤滑に重要な役割をしているとしてい る。本実験において，第一臼齿咬合開始期である 3 週柃 ラットでは，滑膜細胞と連続している $F_{1}$ 層は，分裂能 をもち，細胞層として明確に区分できることから，恐ら く滑膜細胞様の役割をし，関節腔形成もしくは滑液産生 に寄与していると思われる，顎関節を除く他関節では， 関節軟骨表層の滑膜は，胎生後期にすでに存在しないと

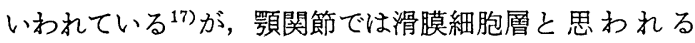
$\mathrm{F}_{1}$ 層が， 3 週齢になっても下顎頭表凮全体を覆ってお り，咬合期の 6 週秢になると， $\mathrm{F}_{1}$ 層は細胞分裂をしな くなり,この時期になってはじめて衰退傾向を示すよう になると思われた。 また，下顎枝骨膜の外膜と連続して いる $\mathrm{F}_{2}$ 層は, 3 週齢では下頡頭の成長に呼応して分裂 していたと思われる未分化な線維芽細胞様細胞が， 6 週 龄になり，咬合が完成し，咀畄運動が活発になるにつ れ，さまさまな細胞環境の影響をらけて，著明に膠原線 維を合成する線維芽細胞に分化していったと思われた.

\section{結語}

3 週粭および 6 週齢ラットにコルヒチンを腹腔内投与 し，下顎頭線維層执よび増殖細胞層の細胞分裂と組織変 化に関し，検索を行い，以下の結果を得た。

1. 3 週齢ラット下顎頭の線維層を形態学的に二層 $\left(\mathrm{F}_{1}\right.$ 層， $\mathrm{F}_{2}$ 層）に区分することができた。

2. 線維層の線維芽細胞様細胞は分裂能を有し，扣よ そ6 週龄で分裂しなくなるが, 増殖細胞層は, 6 週歯で も活発に分裂をしていた．このことから，線維層の細胞 の増加は拉よそ 6 週歯までは, 線維層内部の細胞の増殖 によることが示唆された。

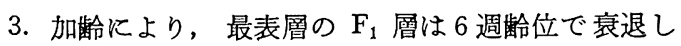
ていくが, $F_{2}$ 層は線維芽細胞へと分化し, 咀嚼運動に 呼応して, 膠原線維を著明に形成していくと思われた。
したがって, 線維層の微細構造に関する検索を行ら場合 には，最表層の $F_{1}$ 層を区分する必要性がある。

本論文の要旨は，第41回日本口腔科学会総会 (1987年 4 月, 東京) 扰よび第32回日本口腔外科学会総会 (1987 年11月，東京）に扣いて発表した。

\section{引 用 文 献}

1) Campos, M.N.M. and Cruz, A.R.: Morphometric study of mandibular condyle of the rat during postnatal development. Acta anat 123: 189-194 1985.

2）森田修一：ラット下顎頭軟骨の生後発育に関す る微細構造学的細胞化学的研究. 日矯掬誌 41 : 171-201 1982.

3）田口 望：顎関節関節軟骨および関節円板の微 細構造に関する研究，日口外誌 26：929-944 1980.

4) Bloom, W. and Fawcett, D.W.: A textbook of histology, 10th Ed., W.B. Saunders Co, Philadelphia, 1975, p 271-273.

5) Durkin, J.F., Heeley, J.D., et al.: The cartilage of the mandibular condyle. Oral Science Reviews 2: 29-99 1973.

6) Beresford, W. A.. Schemes of zonation in the mandibular condyle. Am J Orthod 68: 189-194 1975.

7）塩田 覚, 南 英治, 他：ラットの下顎頭軟骨 に関する電子顕微鏡的研究. 日口外誌 26：6286361980.

8) Silva, D.G. and Hart, J.A.: Ultrastructural Observations on the mandibular condyle of the guinea pig. J Ultrastct Res 20: 227-243 1967.

9) Appleton, J.: The ultrastructure of the articular tissue of the mandibular condyle in the rat. Archs oral Biol 20: 823-826 1975.

10) Wilson, N.H.F. and Gardner, D.L.: The microscopic structure of fibrous articular surfaces. Anat Rec 209: 143-152 1984.

11) Kantomaa, T.: New aspects of the histology of the mandibular condyle in the rat. Acta anat 126: 218-222 1986.

12) Karring, T. and Loe, H.: The use of colchicine for the assessment of mitotic activity in rat oral epithelium. Scand J dent Res 80: 474-485 1972.

13) Tannock, I.F.: A comparison of the relative efficiencies of various metaphase arrest agents. Exp Cell Res 47: 345-356 1965.

14) Viljamaa, P. and Koski, K.: Mitotic activity in the craniofacial cartilages. 1.A comparison of the metaphase arresting efficiency of diffe- 
rent colchicine dosages in the cranial base cartilages of 20-day-old rats. Proc Finn Dent Soc 72: 139-142 1976.

15) Viljamaa, P. and Koski, K.. Mitotic activity in the craniofacial cartilages. 2. Accumulation of arrested metaphages following colchicine injection in 20-day-old rats. Proc Finn Dent Soc 72: 187-190 1976.
16) Viljamaa, P.: Mitotic activity in the craniofacial cartilages. 3. A comparison of the metaphase arresting efficiency of different colchicine dosages in the cranial base cartilages of 40-day-old rats. Proc Finn Dent Soc 77: 179-181 1981.

17) 岡田保典：マウス滑液膜の発育と超微構造. 金 大十全誌 87: 70-89 1978 .

\section{写真の 説 明}

$\mathrm{F}_{1}: \mathrm{F}_{1}$ 層, $\mathrm{F}_{2}: \mathrm{F}_{2}$ 層, $\mathrm{P}$ : 增殖細胞層, $\mathrm{C}:$ 軟骨稩胞層, $\mathrm{S}:$ 滑膜細胞層

写真 13 週齿ラット下顎頭頭頂部 (T.B. 染色, $\times 150)$ 細胞密度の差により弱执大でも $F_{1}$ 層, $\mathrm{F}_{2}$ 層の二層に区分できる。

写真 23 週龄ラット下顎頭辺縁部 (T.B. 染色, $\times 200) \mathrm{F}_{1}$ 層は滑膜細胞層へ, $\mathrm{F}_{2}$ 層は下顎枝 骨膜外層へ連続している。

写真 33 週齡ラット線維層 (T.B. 染色, $\times 500$ ) 紐胞形態は $\mathrm{F}_{1}$ 層では類円形, $\mathrm{F}_{2}$ 層では扁平 である。 $\mathrm{F}_{2}$ 層の基質は著明な膠原線維束がみられる。

写真 $4 \mathbf{a} \cdot 3$ 週龄 ラット線䧽層， b : 6 週龄 ラット線䧽層（T.B. 染色， $\times 400 ） 6$ 週龄になると $\mathrm{F}_{1}$ 層は衰退するが, $\mathrm{F}_{2}$ 層は著明に寥原線維束が増加している。

写真 $5 \mathbf{a}: 3$ 週㱓ラット頭頂部 $\mathrm{F}_{1}$ 層核分裂像. $\mathbf{b}: 3$ 週路ラット辺緑部 $\mathrm{F}_{1}$ 層核分裂像 (T.B. 染色, $\times 450$, インセット部 $\times 1,000)$ 矢印：核分裂像 

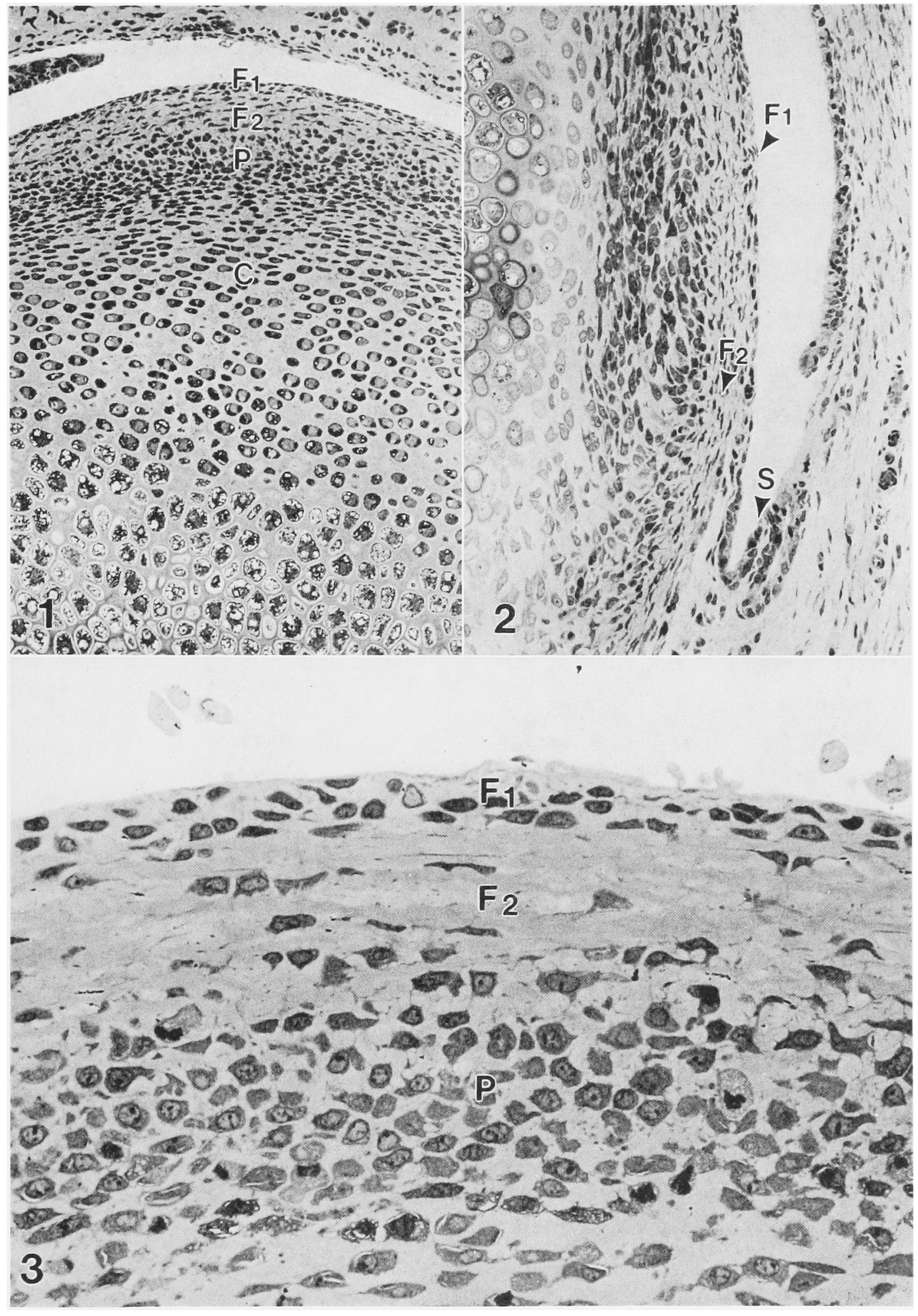


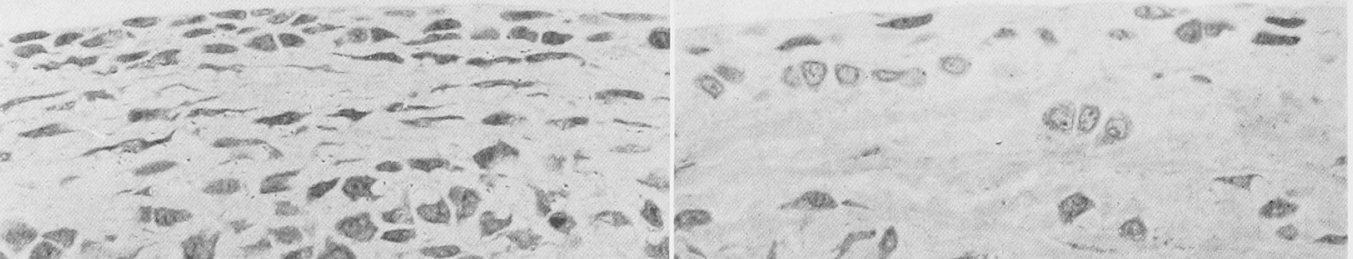

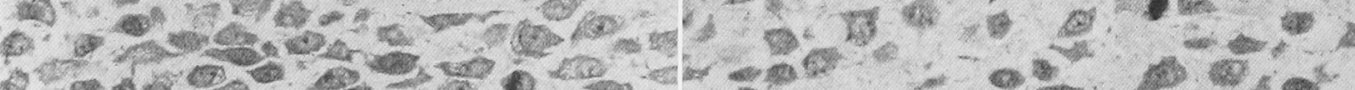

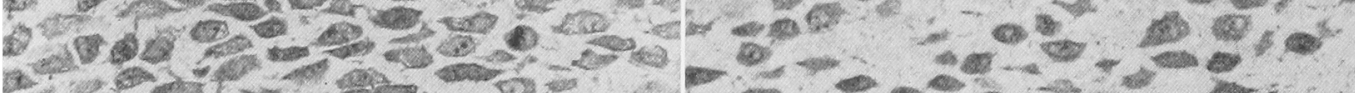
a.

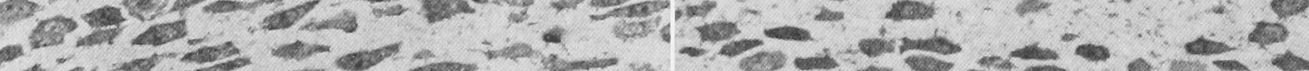

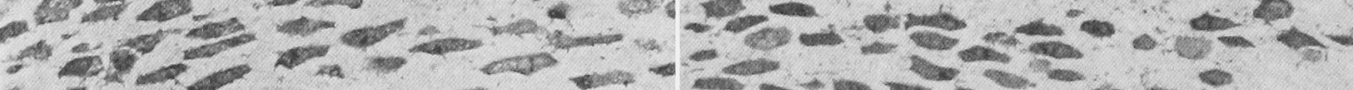

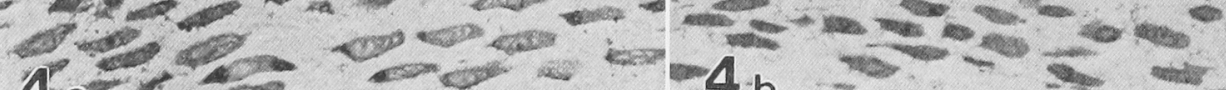

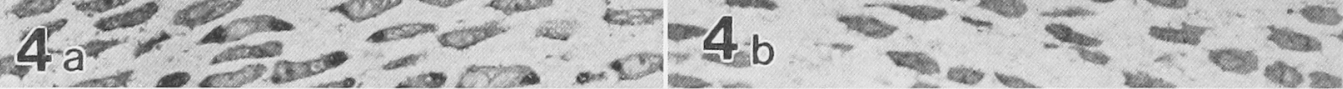

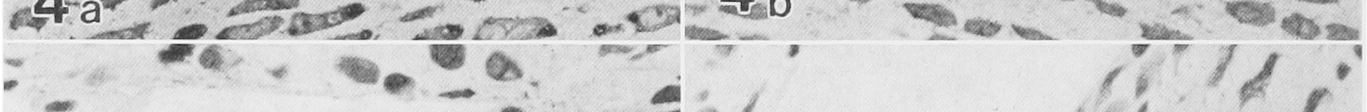

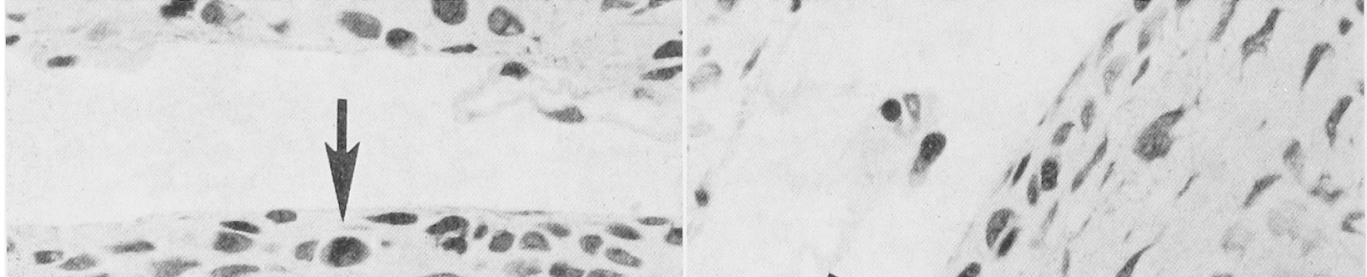

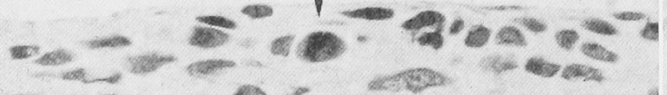

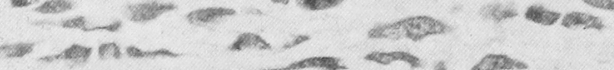

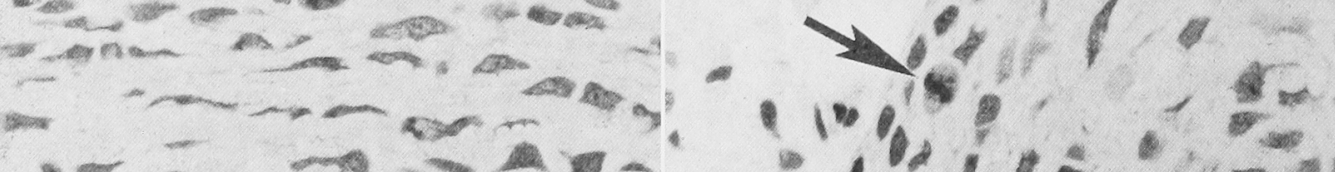

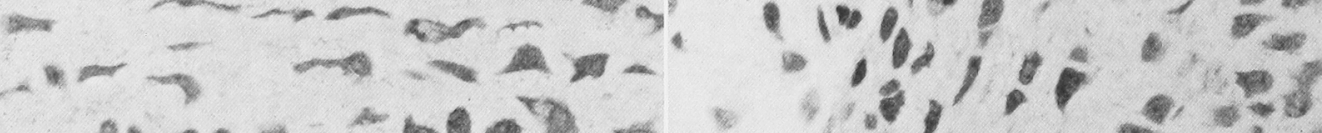

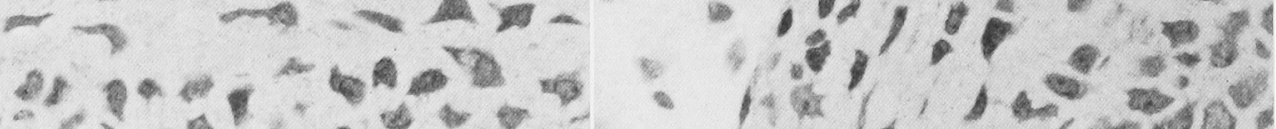

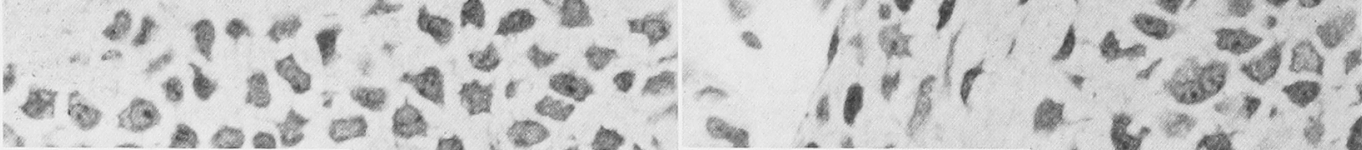

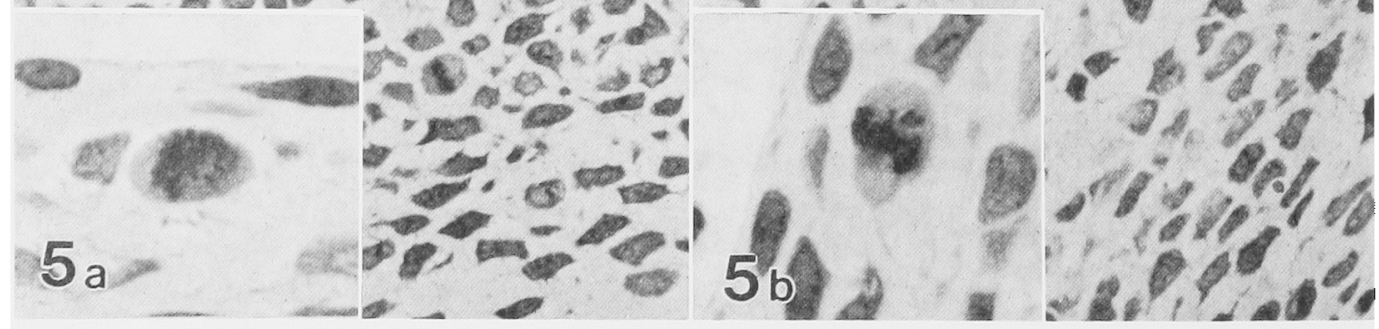

